\title{
Exploring Barriers in Current Inter-enterprise Collaborations: a Survey and Thematic Analysis
}

DOI:

10.1007/978-3-319-94214-8_23

\section{Document Version}

Accepted author manuscript

Link to publication record in Manchester Research Explorer

\section{Citation for published version (APA):}

Kazantsev, N., Pishchulov, G., Mehandjiev, N., \& Sampaio, P. (2018). Exploring Barriers in Current Inter-enterprise Collaborations: a Survey and Thematic Analysis. In B. Shishkov (Ed.), Business Modeling and Software Design: 8th International Symposium, BMSD 2018, Vienna, Austria, July 2-4, 2018, Proceedings (pp. 319-327). (Lecture Notes in Business Information Processing; Vol. 319). Springer Nature. https://doi.org/10.1007/978-3-319-942148_23

\section{Published in:}

Business Modeling and Software Design

\section{Citing this paper}

Please note that where the full-text provided on Manchester Research Explorer is the Author Accepted Manuscript or Proof version this may differ from the final Published version. If citing, it is advised that you check and use the publisher's definitive version.

\section{General rights}

Copyright and moral rights for the publications made accessible in the Research Explorer are retained by the authors and/or other copyright owners and it is a condition of accessing publications that users recognise and abide by the legal requirements associated with these rights.

\section{Takedown policy}

If you believe that this document breaches copyright please refer to the University of Manchester's Takedown Procedures [http://man.ac.uk/04Y6Bo] or contact uml.scholarlycommunications@manchester.ac.uk providing relevant details, so we can investigate your claim.

\section{OPEN ACCESS}




\title{
Exploring Barriers in Current Inter-enterprise Collaborations: a Survey and Thematic Analysis
}

\author{
Nikolay Kazantsev ${ }^{1,2[0000-0002-6812-8786]}$, Grigory Pishchulov 1,3[0000-0001-8787-1869], Nikolay \\ Mehandjiev $^{1}{ }^{[0000-0003-2229-4268]}$ and Pedro Sampaio ${ }^{1[0000-0002-5341-1327]}$ \\ ${ }^{1}$ Alliance Manchester Business School, University of Manchester, M1 3WE, UK. \\ nikolai.kazantsevepostgrad.manchester.ac.uk, \\ n.mehandjiev@manchester.ac.uk, \\ grigory.pishchulov@manchester.ac.uk, \\ pedro.sampaio@manchester.ac.uk \\ ${ }^{2}$ National Research University "Higher School of Economics", 20 Myasnitskaya ul., \\ Moscow, 129000 Russia. \\ ${ }^{3}$ St. Petersburg State University, 7/9 Universitetskaya nab., \\ St. Petersburg, 199034 Russia
}

\begin{abstract}
Original Equipment Manufacturers are increasingly focusing on cooperation with a small number of risk-sharing partners who co-design and deliver key subsystems of the finished product. This trend increases collaboration activities throughout the supply chains involving suppliers of all sizes, including innovative small to medium-sized enterprises. The movement to Industry 4.0 concept such as "lot size of one" and demand-responsive production means these collaborations would be formed "on the fly" to respond to fast changing market needs and ever shorter product lifecycles.

Research has created models and approaches claiming to provide effective software support for such collaborations on demand (also known as instant virtual enterprises); however, these have yet to be implemented and widely applied by suppliers and manufacturers. Research literature, whilst still praising the theoretical advantages and transformative nature of dynamic value chains, is starting to note (as yet undisclosed) economic, managerial and technological concerns that impede uptake of these ideas.

In this paper we analyze exploratory interviews with a number of suppliers in the aerospace industry, and reveal key barriers such as lack of trust, switching costs, information asymmetry and path dependencies that prevent the uptake of short-term collaborations and present them in the sequence they appear forming supplier collaborations on demand.
\end{abstract}

Keywords: Aerospace Supply chains, Collaboration networks, Industry 4.0

\section{$1 \quad$ Introduction}

Traditionally Original Equipment Manufacturers (OEMs) maintain links with hundreds and even thousands of suppliers along their value chains that result in multiple direct connections to procure the requested semi-parts [11], [13]. From the early 
2000s OEMs turn their attention to design-and-build strategies [3], [14] and invite suppliers to co-design components or even subsystems, coordinating clusters of multiple-tier small and medium-sized enterprises (SMEs) [16]. This shifts coordination and financial costs from the OEM onto networks that are expected to reduce leadtimes [2], [10], [12], enable scale economies [13]; facilitate "on-demand" collaborations and make more business opportunities for SMEs available [9], [4]. To bring this vision into reality there are certain collaboration challenges that are considered in this paper in the aerospace industry, characterised by strong and dynamic collaborations spanning complex supply chains.

In this context the leading Multinational Aerospace Corporation (MAC) has initiated streamlining stages of their supply chain avoiding the need to directly link with over 6,000 suppliers, instead collaborating with around 200 trusted tier 1 suppliers that handle transactions with multiple SMEs clusters. One of those clusters, an Association of Aerospace SMEs (AAS), represents a wide spectrum of SMEs mainly supplying MAC. The Association plans to expand its portfolio and to collaborate with new partners for complex products and services in an easy way. Both parties must identify barriers that hamper collaboration and then develop mechanisms to erode them.

Section 2 defines the problem statement for AAS, Section 3 explains the methodology of our research, Section 4 delivers the main barriers to collaboration on-demand in the supply chains of MAC and the Section 5 opens discussion for a number of managerial implications of our findings and reflect on to how the perceived barriers can be addressed by combining technology and managerial solutions.

\section{Problem statement}

Literature review suggests that SME participation in modern supply chains is currently facing several challenges, including perceived costs, risks, loss of flexibility and weakening of strategic independence [13], however, neither precisely systemises current barriers to collaboration nor proposes structures to classify them.

We argue that there is a significant gap between theory and practice and a need to assess key requirements from suppliers to facilitate the MAC vision. Although SMEs are already responsible for approximately $25 \%$ of patents (and therefore very important for MAC), direct collaboration with them is very costly and must be facilitated to enable further innovations into their aircrafts. Moreover, management of delivery ramp-up in time and establishment of new aircraft programmes require additional efforts for enabling short-term collaborations "on-demand" with supplier clusters, often realised in form of virtual enterprises [9].

In contrast to Glock et al. [5] and Zimmer et al. [16] that review approaches to collaborative supplier relationship management from the buyer's perspective, we address collaborations taking place between suppliers themselves to explain which obstacles exist from the suppliers' perspective, as perceived by SMEs in the aerospace industry, with a special focus on collaborations "on demand" requested by Industry 4.0 [2], [10], [12]. In the context of our work, comprehensive studies that analyse collaborations on demand for aerospace industry supplier networks have not yet been studied in 
depth. This raises the importance of identifying barriers to collaboration for aerospace SMEs and developing approaches towards addressing perceived barriers.

\section{Methodology}

The process model of mixed methods methodology comprising literature review, exploratory interviews, thematic analysis [1], information mapping is depicted in Figure 1 and is explained in Subsections $3.1-3.3$. After we identify collaboration obstacles perceived by aerospace SMEs we map them to the stages of instant virtual enterprise formation [6] to identify at which point barriers to demand-driven collaboration occur and open discussion how to address them (further explored in the Subsection 3.3). Since the dataset underpinning this study consists of input from 17 suppliers in the cluster it was possible to identify certain factors that affect each stage of collaboration on demand.

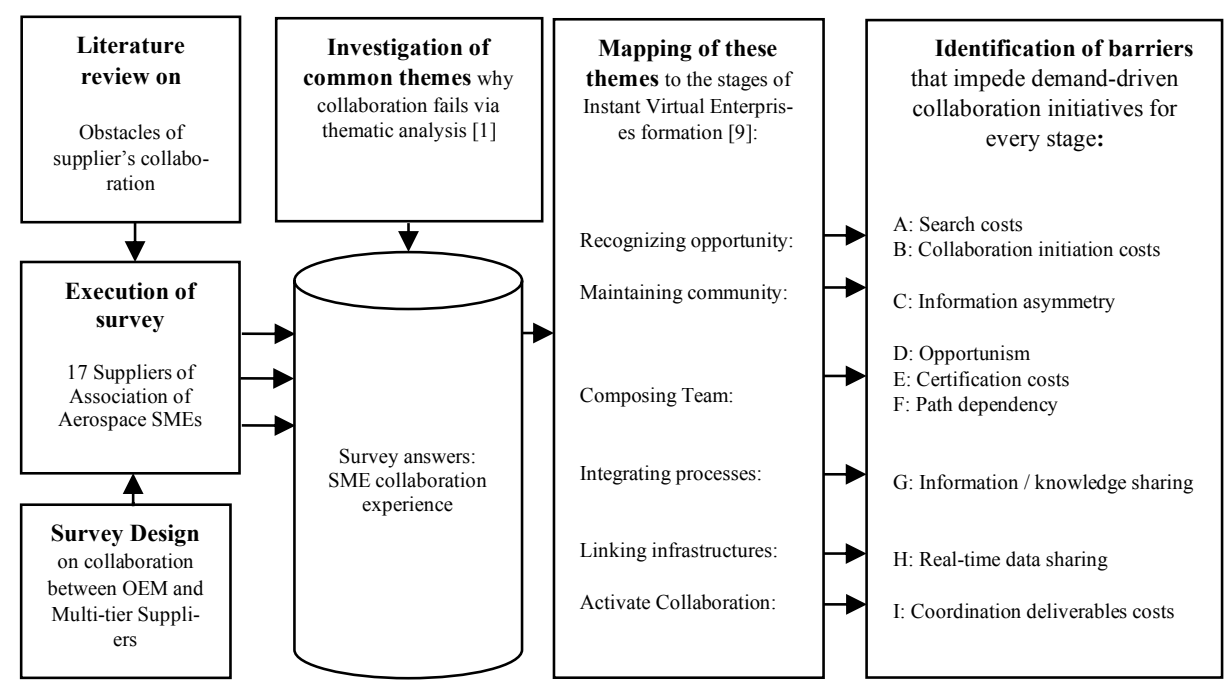

Fig. 1. The process model of research methodology

\subsection{Survey}

In order to explore the barriers that impede collaboration initiatives between manufacturing suppliers and OEMs we carry out exploratory interviews in an Association of Aerospace SMEs (AAS) introduced earlier in the Section 1. In order to construct a representative sample, we have requested AAS to provide access to their suppliers (SMEs) to investigate the main causes that explain why the potential collaborations between them fail. We received a positive response from 17 companies, all headquartered in Germany, which represents approximately $18 \%$ of AAS membership. These companies supply various products (e.g. composite aircraft parts) and services (e.g. product testing and environmental simulation, cabin engineering) to MAC. 
The survey was held in German language with supplier top-level managers (companies' CEOs) during the time span from October 2016 to February 2017 and later translated into English. Responses were collected by an AAS executive via different channels: e-mail, fax, and phone. The semi-structured questionnaire comprised 20 questions, about company information (sector, size, volume, tier number); priorities and activities in searching for supply chain partners; barriers to vertical supply chain integration; their perceived impacts on business; barriers to horizontal collaborations and IT-related barriers to vertical and horizontal networking. Questions were openended in the sense that the respondents were able to indicate any number of items asked for in the respective question; furthermore, the respondents were invited to indicate the strength of the respective item on the Likert scale from 1 to 5 , with 1 being least important. Some of the questions were pre-populated with a number of sample items based on initial information obtained from the respondent companies. These were included in the questionnaire to ensure a consistent perception of questions by the respondents and their responses. Examples of questions included in the questionnaire are indicated below:

- What are the main problems for integration of your company in supply chains of your customers (e.g. OEM, 1st tier suppliers)? What are the main impacts of those problems on your business?

- What are the main problems does your company have with collaboration of SME/organisations in networks?

- Which information deficits regarding Supply Chain Management (SCM) does your company have?

After data collection was finished the answers were translated to English for further analysis.

\subsection{Thematic analysis and identification of barriers}

Amongst approaches to analyse survey data, thematic analysis (as a "method for identifying, analysing and reporting patterns (themes)" [1]) appears to be most suitable for exploring the meaning of unstructured data blocks such as the received survey results. King and Horrocks [8] define the word "theme" as follows: "Themes are recurrent and distinctive features of participants' accounts, characterising particular perceptions and/or experiences, which the researcher sees as relevant to the research question" (p. 150). To formalise barriers to collaboration we have followed the process from Braun and Clarke [1]: (1)Transcribe data, noting down initial ideas; (2) Code interesting features of the data in a systematic fashion across the entire data set, collating data relevant to each code; (3) Collate codes into potential themes (barriers), gathering all data relevant to each potential theme (barrier); (4) Check if the themes (barriers) work in relation to the coded extracts (Level 1) and the entire data set (Level 2), generating a thematic 'map' of the analysis; (5) Ongoing analysis to refine the specifics of each theme (barrier), and the overall story the analysis tells, generating 
clear definitions and names for each theme (barrier); (6) Selection of vivid, compelling extract examples, final analysis of selected extracts, relating back of the analysis to the research question and literature, producing a scholarly report of the analysis.

\subsection{Classification of barriers}

To classify the identified themes/barriers we collate them into stages of collaboration on demand that are represented in the model of instant virtual enterprise formation [6], [9]. This model explains the behaviour of SMEs when they react to a new business opportunity (call for tender) from manufacturers and cannot fulfil this opportunity alone - in this case suppliers create a virtual entity to collaborate on demand. Once the new entity puts their bid and wins a tender, collaborative SMEs link their processes, infrastructures and further activate an instant virtual enterprise to respond to this business opportunity (Fig. 2).

This representation is very similar to the relationships between MAC and AAS. To open discussion on the erosion of the identified themes/barriers, once they were formed, they were grouped into higher-level factors and mapped to the formation stages from Figure 2. The results of the mapping are presented in Table 1.
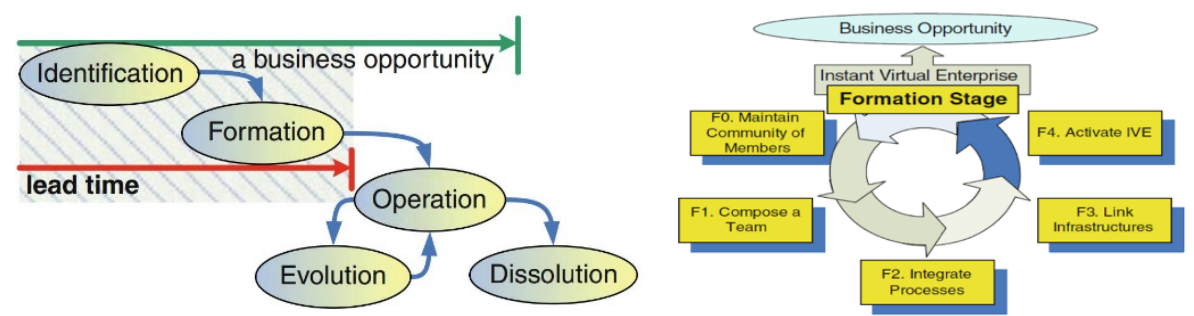

Fig. 2. Formation of instant virtual enterprise and its stages [9]

\section{The identified barriers to collaboration between suppliers and aerospace manufacturer}

The survey has identified that one of the main intentions of SMEs is to integrate into the value chains of large-scale manufactures. It is caused by the intention to expand business portfolio and to get constant amount of orders, since many of them experience drawbacks due to timely missing, timely under-utilized capacities and constant overhead costs. Additionally, many SMEs are considered unfit for OEMs business opportunities due to company size, scaling capacity towards order volumes, scheduling capabilities, finance requirements and they request collaboration with the similar suppliers to cover gaps in capacities, capabilities and expertise to fulfil the purchase conditions of OEM.

However, in the reality such plans to collaborate often fails due to the issues depicted in Table 1. 
Table 1. The identified barriers to collaboration

\begin{tabular}{|c|c|}
\hline $\begin{array}{l}\text { Formation } \\
\text { steps }\end{array}$ & Main barriers and its manifestations \\
\hline $\begin{array}{l}\text { Identification } \\
\text { of a business } \\
\text { opportunity } \\
\text { (derived from } \\
\text { Call for Ten- } \\
\text { ders) }\end{array}$ & $\begin{array}{l}\text { A: Costs of suppliers for searching, processing and storing infor- } \\
\text { mation } \\
\text { 1. Lack of Call for Tenders visibility to SME suppliers } \\
\text { 2. Information gaps due to vague CfT specifications } \\
\text { 3. Long time to find applicable regulations } \\
\text { 4. Information loss during communication ("Chinese whispers" } \\
\text { effects) } \\
\text { B: Costs of suppliers for initiating collaboration } \\
\text { 1. Offline networking takes time to find new projects } \\
\text { 2. SMEs' inability to exert marketing effort for attracting OEMs } \\
\text { 3. Differences in legal, tax and patent systems }\end{array}$ \\
\hline $\begin{array}{l}\text { F0: Maintain } \\
\text { community of } \\
\text { members }\end{array}$ & $\begin{array}{l}\text { C: Information asymmetry } \\
\text { 1. Lack of knowledge regarding network collaboration } \\
\text { 2. Lack of knowledge regarding to Industry } 4.0\end{array}$ \\
\hline $\begin{array}{l}\text { F1: Compose a } \\
\text { team }\end{array}$ & $\begin{array}{l}\text { D: Opportunism of suppliers } \\
\text { 1. Extract benefits from collaboration, give nothing in exchange } \\
\text { 2. Lack of trust, espionage for innovations } \\
\text { 3. Unreliable partnerships (disruptions in deliveries) } \\
\text { E: Certification costs } \\
\text { 1. SMEs' inability to certify its market reputation } \\
\text { 2. Expensive certifications: NADCAP, GRAMS, environment } \\
\text { (ISO 9100, 16949) } \\
\text { 3. Too complex accreditation processes \& qualification checks } \\
\text { 4. Overprotection of property rights: direct contracts } \\
\text { F: Path dependency of manufacturers } \\
\text { 1. OEMs do not intend to change their existing suppliers } \\
\text { 2. OEMs disseminate CfTs to tier-1 suppliers only } \\
\text { 3. OEMs dismiss the interests of domestic suppliers } \\
\text { 4. OEM's inability to share risks with network partners }\end{array}$ \\
\hline $\begin{array}{l}\text { F2: Integrate } \\
\text { processes }\end{array}$ & $\begin{array}{l}\text { G: Challenges with Information and knowledge sharing } \\
\text { 1. Different data protection policies, information privacy } \\
\text { 2. Delays in information sharing about demand changes } \\
\text { 3. Lack of infrastructure knowledge: time-consuming calibration }\end{array}$ \\
\hline $\begin{array}{l}\text { F3: Link in- } \\
\text { frastructures }\end{array}$ & $\begin{array}{l}\text { H: Challenges with real-time data sharing } \\
\text { 1. Poorly structured data exchange policies } \\
\text { 2. Use of proprietary IT without standardised data transfer } \\
\text { 3. Variety of IT systems in use }\end{array}$ \\
\hline $\begin{array}{l}\text { F4: Activate } \\
\text { Instant Virtual } \\
\text { Enterprise }\end{array}$ & $\begin{array}{l}\text { I: Costs of leading supplier for coordination deliverables } \\
\text { 1. Missing standards and interfaces in communication } \\
\text { 2. Problems signalled by the customer too late, quick fixes } \\
\text { 3. OEM requests testing too late, deadline pressure }\end{array}$ \\
\hline
\end{tabular}




\section{Discussion and Future Work}

Our research shows limited collaboration along manufacturer value chains due to the list of factors depicted in Table 1. One of the main reasons (identified as the issue of distrust and competitive pressures) impedes major collaboration initiatives between SMEs operating across and within value chain tiers. To transform and improve competitiveness, companies need to adopt more cooperative interaction patterns that include collaborative governance rules, goal-based team composition and interorganisational process coordination to lower transaction costs on short-term (demanddriven) collaboration.

Information asymmetry is another obstacle that restricts an access to the context information that is retained by an intermediary instead of propagating it to other players in the chain (e.g. order situation of the customer). Suppliers should be empowered with a digital platform that ensures the integrity of collaboration rules, transparent decomposition of large-scale tender descriptions into well-specified business process tasks and semi-automated supplier matchmaking to business process tasks via semantic technology and recommender systems.

Switching costs and path dependencies represent another area of problems that have to be solved in order to enforce collaborations along value chains. In particular in the area of data sharing, concerns are raised relating to the level of suppliers' access to shop floor data given the potential risk of cyber espionage and access to key corporate secrets. This in turn raises the prospect of a data sharing paradox [7] in Industry 4.0 where stewardship of the data is in the hands of companies that may have no interest in sharing information with collaborating partners. This paradox opposes the intention to develop mechanisms for customer order monitoring through highly visible production chains. Notwithstanding, effective data sharing is a precondition to generate "big data" scale datasets supporting efficient production and supply chain management. We are not aware of comprehensive studies that solve this data sharing paradox in Industry 4.0 and we aim to investigate how information privacy concerns between collaborating suppliers and OEMs is correlated with successful business opportunity delivery among other factors in our future works. Additionally, we aim to explain the rationale underpinning the identified collaboration barriers and predict potential supplier behaviour under different set of potential interventions in the value chain from the perspective of the Transaction Costs Theory.

\section{Acknowledgements}

This work was supported by the European Commission under the European Union's Horizon 2020 research and innovation programme (grant agreement $n^{\circ} 723336$ ). 


\section{References}

1. Braun, V., Clarke, V. (2006). Using thematic analysis in psychology. Qualitative Research in Psychology, 3(2), 77-101.

2. Brettel, M., Friederichsen, N., Keller, M., \& Rosenberg, M. (2014). How virtualization, decentralization and network building change the manufacturing landscape: An industry 4.0 perspective. International Journal of Mechanical, Industrial Science and Engineering, $8(1), 37-44$.

3. Broft, R., Badi, S. M., Pryke, S. (2016). Towards supply chain maturity in construction. Built Environment Project and Asset Management, 6(2), 187-204.

4. Cisneros-Cabrera, S., Ramzan, A., Sampaio, P., Mehandjiev, N. (2017, September). Digital Marketplaces for Industry 4.0: A Survey and Gap Analysis. In Working Conference on Virtual Enterprises (pp. 18-27). Cham: Springer.

5. Glock, C.H., Grosse, E.H., Ries, J.M. (2017). Decision support models for supplier development: Systematic literature review and research agenda. International Journal of Production Economics, 193, 798-812.

6. Grefen, P, Mehandjiev, N., Kouvas, G., Weichhart, G., \& Eshuis, R. (2009). Dynamic business network process management in instant virtual enterprises. Computers in Industry, 60(2):86-103. doi: 10.1016/j.compind.2008.06.006. URL http://doi.org/10.1016/j.compind.2008.06.006.

7. Hoel, T., Mason, J., \& Chen, W. (2015). Data sharing for learning analytics-Questioning the risks and benefits. In Proceedings of the 23rd International Conference on Computers in Education. China: Asia-Pacific Society for Computers in Education (Hangzhou).

8. King, N., Horrocks, C. (2010). Interviews in qualitative research. Sage.

9. Mehandjiev, N., Haemmerle, A., Grefen, P., Ristol, S., 2010. Towards New Frontiers: CrossWork. In: Mehandjiev, N., Grefen, P. (Eds.) Dynamic Business Process Formation for Instant Virtual Enterprises. London: Springer, pp. 13-23.

10. Müller, J., Dotzauer, V., Voigt, K. I. (2017). Industry 4.0 and its Impact on Reshoring Decisions of German Manufacturing Enterprises. In Supply Management Research (pp. 165179). Springer Fachmedien Wiesbaden.

11. Pritchard, D., MacPherson, A. (2005). Boeing's diffusion of commercial aircraft design and manufacturing technology to Japan: Surrendering the US aircraft industry for foreign financial support. Canada-United States Trade Center, Occasional Paper, (30).

12. Smit, J., Kreutzer, S., Moeller, C., Carlberg, M., 2016. Industry 4.0. European Parliament, Document No. IP/A/ITRE/2015-02.

13. Simchi-Levi, D., Kaminsky, P., Simchi-Levi, E., (2008). Designing and managing the supply chain: Concepts, strategies, and cases. $3^{\text {rd }}$ ed., New York: McGraw-Hill.

14. Tiwari, M. (2005). An exploration of supply chain management practices in the aerospace industry and in Rolls-Royce (Doctoral dissertation, Massachusetts Institute of Technology).

15. Zimmer, K., Fröhling, M., Schultmann, F. (2016). Sustainable supplier management $-a$ review of models supporting sustainable supplier selection, monitoring and development. International Journal of Production Research, 54 (5), 1412-42.

16. Link: European Commission. What is an SME? http://ec.europa.eu/growth/smes/businessfriendly-environment/sme-definition en (accessed 10.05.2018) 